\title{
GIANT HAND LIPOMA - CASE REPORT OF A RARE LOCALIZATION OF A COMMON TYPE OF TUMOR
}

\author{
Radivojcevic Uros, ${ }^{1,2}$ Ilic B. Milena, ${ }^{2}$ Vulovic D. Dejan ${ }^{1,2}$ \\ ${ }^{1}$ Centre for Plastic Surgery, Clinical Centre Kragujevac, Serbia \\ ${ }^{2}$ Faculty of Medical Sciences, University of Kragujevac, Serbia
}

Primljen/Received 25. 04. 2016. god.

Abstract: Introduction: A lipoma is a benign tumor of the adipose tissue and the most common tumor of the subcutaneous tissue which is most commonly found on the trunk. It appears as a round or oval subcutaneous mass of soft consistency, which is not attached to the skin or to the deeper tissues. Its growth can cause compressive symptoms, the most common being pain and paresthesia.

Case report: Considering the fact that lipomas very rarely occur in the hand and foot, in this paper we present a case of a large lipoma in the hand of a 70-year-old female patient, with a subcutaneous tumor, in the area of the ulnar side of the left palm, and the pain and tingling in the fourth and fifth finger.

Longitudinal incision on the medial side of the palm and transversal incision up to the proximal palmar crease were performed under general endotracheal anesthesia. The extirpated tumor was, due to its dimensions $(5.6 \times 3.4$ $\mathrm{x} 2.5 \mathrm{~cm}$ ), categorized as a giant hand lipoma. A histopathological analysis confirmed the diagnosis of lipoma.

Conclusion: A hand lipoma requires surgical treatment exclusively, involving a qualified hand surgeon, which is important because of the high functional and aesthetic importance of the hand.

Keywords: lipoma, hand tumors, hand lipoma.

\section{INTRODUCTION}

The most common tumor of the subcutaneous tissue is a lipoma, which is a benign tumor of the adipose tissue. Different morphological variations of this tumor have been described such as fibrolipoma, myxolipoma, myolipoma, chondroid lipoma, pleomorphic lipoma, angiolipoma and other (1). It is not attached to the skin or to the deeper tissues, usually appears as a round or oval bulge beneath the skin of soft consistency. It is noted that lipomas found in the superficial soft tissues usually have a well developed capsule, while tho-
Prihvaćen/Accepted 07. 06. 2016. god.

se found in the deeper structures are not clearly separated from the surrounding tissue. Histologically, lipomas are composed of mature adipocytes and very rarely they undergo malignant alteration $(1,2)$.

Compressive symptoms may occur and the most common are pain and paresthesia. Lipomas can occur anywhere on the body where adipose tissue is present, but they most often appear on the trunk, shoulders and neck. Considering the fact that lipomas in the hand are very rare (3), the aim of this paper is to present a rare localization of a giant lipoma.

\section{CASE REPORT}

A 70-year-old female patient was admitted to the clinic with subcutaneus nodule on the ulnar side of the left palm. There were no pathological changes in the skin, the tumor had a soft consistency and irregular shape, and the mostly it was movable towards the deeper structures. The patient complained of pain and tingling in the fourth and fifth finger, as well as of the aesthetic appearance of the left palm. Additional examinations were conducted: ultrasonography and CT (Figure 1) by which a presence of a homogenous tumor was identified, of relatively clear demarcation and without visible internal vascularization.

Under general endotracheal anesthesia, using a tourniquet and surgical loops, a longitudinal incision was performed on the medial side of the palm while the transversal incision was performed up to the proximal palmar crease. After that, the tumor was separated from the surrounding tissues and it was seen that one part of it spreaded below the flexor tendons and above the hypothenar muscles, while the other part of it extended into the region of the fourth commissure. Macroscopically, the tumor resembled a lipoma (Figure 2) of a maximum length $56 \mathrm{~mm}$, maximum width $34 \mathrm{~mm}$ and maximum 


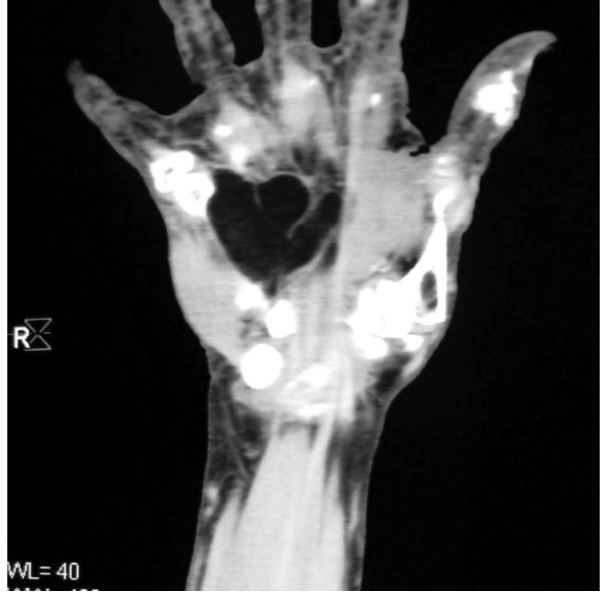

Figure 1. Computed tomography showing the tumor with relatively clear demarcation and spreading tendency, therefore condensing the surrounding structures in the palm

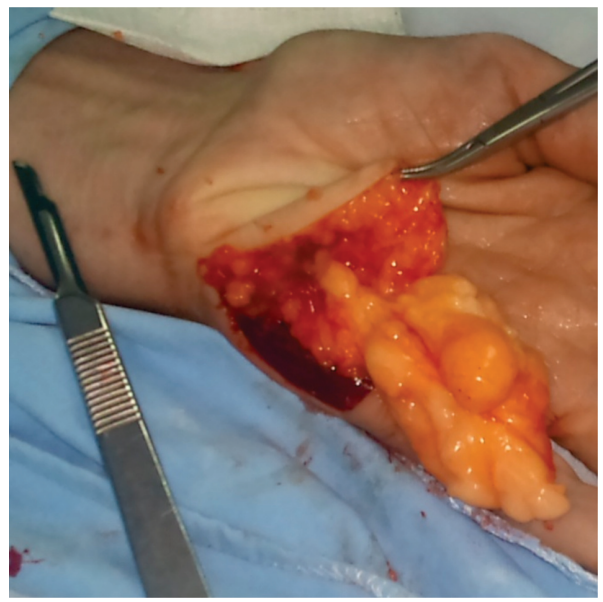

Figure 2. Intraoperative appearance of the tumor, of irregular shape, recalls as lipoma

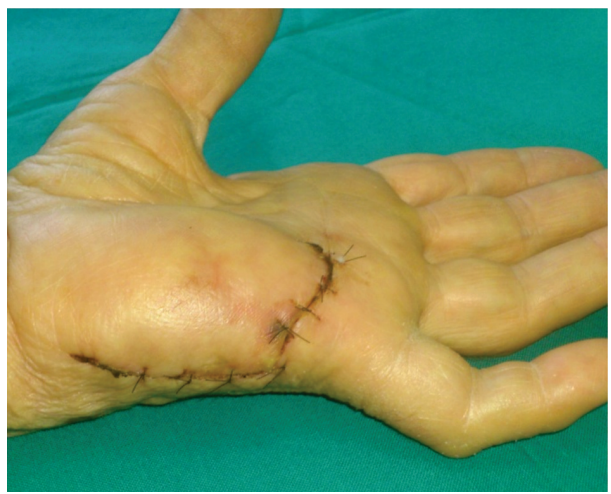

Figure 3. The patent's hand on the fifth postoperative day

thickness $25 \mathrm{~mm}$. It was completely removed and sent for histopathological analysis. The wound was closed with individual stiches (polyamide, 5-0) while vacuum drains were placed through a separate incision. There were no complications in the postoperative period. On the second postoperative day, the drain was removed

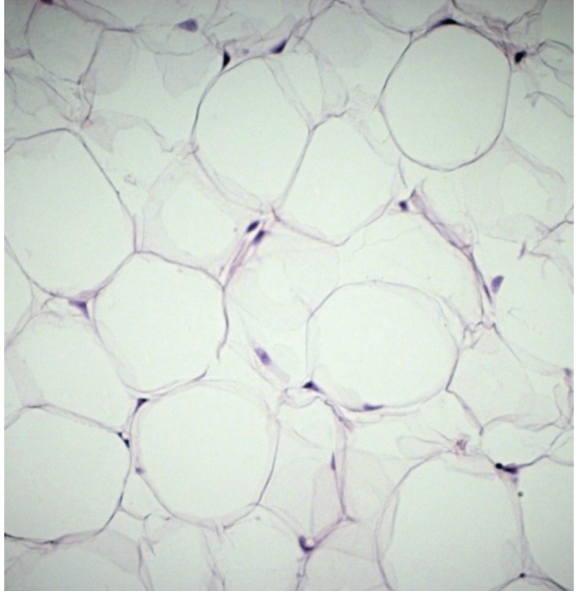

Figure 4. Histological appearance of the lipoma: uniform cells with cytoplasmic vacuoles suppressing the nucleus towards the cell membrane (H\&E x200)

and the patient was discharged on the third day after surgery with a reduced pain and tingling and without signs of fluid accumulation in the wound (Figure 3). The wound healed per primam and the stiches were removed on the tenth postoperative day. The pathohistological report (Figure 4) confirmed that it was a lipoma.

The patient was referred to physical therapy. On the follow-up examination, one month after surgery, there was no subjective discomfort, the scar healed properly and was in the maturation phase, while the function of the hand was normal, with good neurocirculatory function of the IV and V finger.

\section{DISCUSSION}

Benign subcutaneous tumors of the hand are relatively rare and the most common among them are ganglion cyst, giant cell tumor and hemangioma. Although lipomas are the most common subcutaneous tumors, their occurrence in the hand is very rarely reported. The first documented case of a lipoma in the hand dates from 1959 when McEnery at al. described this tumor in the palm (4). Later, other cases of different localizations of hand lipoma were described $(5,6)$, such as thenar (7) or fingers $(8,9)$.

Hand lipoma is usually found on the palm and palmar side of the fingers, while it is rarely formed on the dorsal side of the hand, due to poorly developed fat tissue. Considering a subtle hand morphology, comprised of a of various tissues seated in a relatively narrow space, the symptomatology in these cases is diverse and it is most often manifested with paresthesia and pain. These symptoms are the most noticeable when the lipoma is localized in the carpal canal $(10,11,12)$. Limited and difficult movement of the fingers occur when the tumor compresses the muscles and tendons of the hand, which has a high functional significance for daily activities. 
Moreover, depending on the size of tumor, there are also varying degrees of aesthetic impairment due to the fact that the hand is an exposed part of the body (13).

Moreover, lipomas can grow large in size; however, it should be pointed out that the concept referring to a large tumor in surgery does not depend mainly on its size, but also on its anatomical localization, as well as functional and aesthetic importance of that area. With the consensus in the literature that any hand lipoma that has a maximal diameter greater than $5 \mathrm{~cm}$ belongs to the group of giant lipomas $(13,14,15)$, we classified this lipoma into the group of rare giant hand lipomas.

A diagnosis of the lipoma is primarily based on clinical examination and intraoperatively, while it is finally made on the basis of a pathohistological analysis. However, due to the occasional presence of differential diagnostic dilemmas and possible occurence of liposarcoma in the hand (16), in order to diagnose a hand lipoma there is sometimes a need for additional procedures, such as ultrasonography, computed tomography and MRI (17). This is important in cases when the tumor is large, firmer in consistency and to a certain degree attached to the deeper tissues. Using the above mentioned diagnostic procedures, a lipoma can be differentiated from other tumors, and it is of particular importance to exclude the existence of a deep hemangioma or sarcoma (18).

The only definitive method for successful lipoma treatment is surgery that must be performed under general or regional anesthesia and in a bloodless operative field, which is achieved by placing a pneumatic tourniquet. Besides, in most cases, it is necessary to perform surgery with the use of magnification with binocular surgical loupes and appropriate surgical instruments for hand surgery. Planning incisions in the hand has to be in accordance with the general principles of plastic surgery. The incisions are planned in order to avoid occurence of desmogenous finger contractures. Sometimes, it is necessary to make a vertical incision, due to the easier extirpation of a tumor in the hand and that kind of incision requires a Z-plasty. During surgery, it is very important, not only to remove the tumor completely, but also to avoid the damage of healthy tissues, particularly neurovascular elements. Considering the fact that a cavum remains after extripation of large tumors, wound drainage is very important and it is recommended to be performed through a separate incision, using a firm and fixed multi-perforated silicone catheter attached with a vacuum system $(19,20)$.

Postoperative complications are possible, such as hematoma, seroma, dehiscence, infection, lesions in the deeper structures during surgery, desmogenous contracture in improperly placed incisions and recurrence, if the tumor is not completely removed. The most common specific complication is digital nerve lesion. During the whole treatment, a postoperative intensive and qualified physical therapy is of a great importance $(3,20,21)$.

\section{CONCLUSION}

Diagnosis of subcutaneous tumors of the hand should be exact and, for this reason, additional diagnostic procedures are necessary such as ultrasonography, CT, MRI and angiography. This is particularly important for large tumors, such as the giant lipoma in the hand which is presented in this paper.

A lipoma in the hand is exclusively treated surgically and includes the participation of a qualified hand surgeon, which is important because of a great functional and aesthetic character of the hand. The tumor presented in this paper had a rare localization for its kind and larger dimensions in relation to the area it was encountered in.

\section{Conflict of interest}

The autors declare that there are no conflicts of interest.
Abbreviations
CT - computed tomography
MRI - Magnetic resonance imaging

\title{
Sažetak
}

\section{GIGANTSKI LIPOM ŠAKE - PRIKAZ SLUČAJA RETKE LOKALIZACIJE ČESTOG TUMORA}

\author{
Radivojcevic Uros, ${ }^{1,2}$ Ilic B. Milena, ${ }^{2}$ Vulovic D. Dejan ${ }^{1,2}$ \\ ${ }^{1}$ Centre for Plastic Surgery, Clinical Centre Kragujevac, Serbia \\ ${ }^{2}$ Faculty of Medical Sciences, University of Kragujevac, Serbia
}

Uvod: Lipom je dobroćudni tumor masnog tkiva i najčešći tumor potkožnog tkiva koji se najčešće javlja na trupu. Prezentuje se kao okrugao ili ovalni potkožni čvor, mekše konzistencije, koji nije fiksiran za kožu, a 
najčešće ni za dublja tkiva. Svojim rastom može da uzrokuje kompresivne simptome, od kojih su najčešći bol i parestezija.

Prikaz slučaja: Obzirom da se lipomi veoma retko javljaju na šaci i stopalu, u ovom radu prikazujemo veliki lipom šake kod pacijentkinje stare 70 god. sa potkožnim izraštajem u predelu ulnarne strane levog dlana i bolom i trnjenjem u četvrtom i petom prstu. U opštoj endotrahealnoj anesteziji je urađena longitudinalna incizija na medijalnoj strani dlana i poprečna incizija do prok-

\section{REFERENCES}

1. Rosai J. Rosai i Ackerman-ova kirurška patologija. 9. prevedeno izdanje. Zagreb: Školska knjiga; 2010.

2. Kumar V, Abbas AK, Fausto N, Mitchell RN. Robinsove osnove patologije. 8. prevedeno izdanje. Beograd: Datastatus; 2010

3. Bancroft LW, Kransdorf MJ, Peterson JJ, O'Connor MI. Benign fatty tumors: classification, clinical course, imaging appearance and treatment. Skeletal Radiol. 2006; 35(10): 719-33.

4. McEnery ET, Schmitz RL, Nelson PA. Palmar lipoma: report of a case. AMA Arch Surg. 1959; 79(4): 699-700.

5. Phalen GS, Kendrick JI, Rodriguez JM. Lipomas of the upper extremity. A series of fifteen tumors in the hand and wrist and six tumors causing nerve compression. Am J Surg. 1971; 121(3): 298-306.

6. Chatterton BD, Moores TS, Datta P, Smith KD. An exceptionally large giant lipoma of the hand. BMJ Case Rep. 2013 Jul 8;2013. pii: bcr2013200206. doi: 10.1136/bcr-2013-200206.

7. Grivas TB, Psarakis SA, Kaspiris A, Liapi G. Giant lipoma of the thenar - case study and contemporary approach to its aetiopathogenicity. Hand. 2009; 4(2): 173-6.

8. Ramirez-MontaZo L, Lopez RP, Ortiz NS. Giant lipoma of the third finger of the hand. Springerplus. 2013;2(1): 164.

9. Gupta A, Singal R, Mittal A, Goyal M. Report of two cases of subcutaneous lipoma over the finger and review of literature: case series: benign tumour. Musculoskelet Surg. 2011; 95(3): 247-9.

10. Jalan D, Garg B, Marimuthu K, Kotwal P.Giant lipoma: an unusual cause of carpal tunnel syndrome. Pan Afr Med J. 2011; 9: 29 .

11. Fazilleau F, Williams T, Richou J, Sauleau V, Le Nen D. Median nerve compression in carpal tunnel caused by a giant lipoma. Case Rep Orthop. 2014; 2014: 654934.

\section{Correspondence to / Autor za korespondenciju}

Dejan D. Vulovic

Centre for Plastic Surgery, Clinical Centre "Kragujevac"

Address: Zmaj Jovina 30, 34000 Kragujevac, Serbia

phone number: +38162307816

e-mail: dejanavu@eunet.rs simalne dlanske brazde. Ekstirpiran tumor je zbog svojih dimenzija $(5,6 \times 3,4 \times 2,5 \mathrm{~cm})$ kategorisan kao gigantski lipom šake. $\mathrm{U}$ postoperativnom toku nije bilo komplikacija, a rana je zarasla per primam. Histopatološkom analizom je potvrđena dijagnoza lipoma.

Zaključak: Lečenje lipoma šake je isključivo operativno i podrazumeva učešće hirurga koji je edukovan za hirurgiju šake, što je od važnosti zbog velikog funkcionalnog i estetskog značaja šake.

Ključne reči: lipom, tumori šake, lipom šake.

12. Bagatur AE, Yalcinkaya M. Unilateral carpal tunnel syndrome caused by an occult palmar lipoma. Orthopedics. 2009; 32(10). doi: 10.3928/01477447-20090818-20.

13. Yadav SP, Jategaonkar PA, Haldar PJ. Giant hand lipoma revisited: report of a thenar lipoma \& its literature review. J Hand Microsurg. 2013; 5(2): 84-5.

14. Inaparthy P, Southgate GW. Giant lipoma of hand: a case report. European Journal of Orthopaedic Surgery and Traumatology. 2006; 16(3): 251-2.

15. Fnini S, Hassoune J, Garche A, Rahmi M, Largab A. Giant lipoma of the hand: case report and literature review. Chir Main. 2010; 29(1): 44-7.

16. Kooby DA, Antonescu CR, Brennan MF, Singer S. Atypical lipomatous tumour/well differentiated liposarcoma of the extremity and trunk wall: importance of histological subtype with treatment recommendations. Ann Surg Oncol. 2004; 11(1): 78-84.

17. Pagonis T, Givissis $\mathrm{P}$, Christodoulou A. Complications arising from a misdiagnosed giant lipoma of the hand and palm: a case report. J Med Case Reports. 2011; 5: 552.

18. Brisson M, Kashima T, Delaney D, et al. MRI characteristics of lipoma and atypical lipomatous tumor/well-differentiated liposarcoma: retrospective comparison with histology and MDM2 gene amplification. Skeletal Radiol. 2013; 42(5): 635-47.

19. Athanasian EA. Bone and Soft Tissue Tumors. In: Green DP. Operative Hand Surgery. London: Churchill Livingstone, 2011: 2141-95.

20. Levi B, Chung KC. Hand Tumors. In: Grabb and Smith's Plastic Surgery. 7 th ed. Philadelphia: Lippincott, Williams and Wilkins, a Wolters Kluwer business, 2014: 868-77.

21. Gan LP, Tan JS. Concomitant Lipoma and Ganglion Causing Ulnar Nerve Compression at the Wrist: A Case Report and Review of Literature. Ann Plast Surg. 2016; 76(4): 472-3. 